\title{
Scour prediction and scour protections in offshore wind farms
}

\author{
Clara Matutano*, Vicente Negro, Jose-Santos López-Gutiérrez, M. Dolores Esteban
}

\begin{abstract}
A B S T R A C T
This paper is the result of research whose main objective is to analyse different methods used for the prediction of maximum scour depth and scour extension, and for the design of scour protections in offshore wind farms located in shallow water, using medium and large diameter monopile foundations. Physical agents such as waves, currents and wind play a major role in the design of structures like offshore farms. As a result, the study has highlighted the need for introducing experience backed climate monomials such as the dimensionless wave height parameter $\left(H_{0}\right)$ and proposes the use of formulations that can express the extent of scour protections as a function of waves in transitional waters.
\end{abstract}

\section{Introduction}

The increasing development in offshore wind farm planning and construction in recent years is associated with the need to improve the design of these structures and to optimize the costs involved in their implementation. Short term experience in the field of offshore wind technology has led to methodologies being established in order to recommend all necessary steps in the design of these facilities [1]. On the other hand, it is important to know how the presence of offshore wind farms may affect littoral processes to prevent or avoid this impact [2].

Nowadays, the cost of offshore wind turbine support structures represents almost $30 \%$ of the total cost of an offshore wind farm [3]. During 2011, 866 MW were installed, representing almost $23 \%$ of total capacity installed so far (3812.6 MW). The target of between 40,000 and 50,000 MW is expected to be achieved in the year 2020, according to the Seventh Framework Programme (FP7). However, despite the current boom in offshore wind farms, there is still a need for research on issues such as the design of foundations and transition components or the sizing of scour protection which is dealt with in this paper.

The scour phenomenon jeopardizes the operating capacity of offshore structures since it compromises their stability. So far, different investigations have been carried out linked to the origin of the scour process and its development in bridge piers (generally under steady current conditions). The study of this phenomenon in the marine environment for different authors such as [4] or [5], began only a few years ago and considered that these structures are subjected to currents, tides and waves in a different regime than bridge piers over rivers studied by authors such as [6].

Much research work carried out on scour phenomenon in offshore wind farms with monopile foundations led to different formulations and methods that allow this phenomenon to be characterised by predicting maximum scour depth $\left(S_{\max }\right)$ and maximum scour extension ( $\left.L_{\text {ext }}\right)$ in the vicinity of the pile. Some of this research, such as [7] and [8], enabled scour depth development over time to be assessed.

The characterization of this phenomenon, knowing the serious consequences related to its occurrence (loss of structural stability, sliding, etc.) has, over the last few years, brought to the fore the need to develop methods and systems for protecting these offshore structures, as recommended in Ref. [9]. Scour protections are required to prevent problems of structural stability and may also be required to protect the inter-array and export cables [10].

A thorough review of offshore wind farms has been performed in order to evaluate the different methods used in the prediction of maximum scour depth and in the design of scour protections in them. The main meteocean characteristics (maritime climate, correlation between wave height and period associated with a given recurrence), the type of foundation and main dimensions, and the type of scour protection used (weight average, nominal diameter in the case of breakwater type protection, width and performance) have been defined from one of the first experiences in 1991 (Vindeby Wind Farm, Denmark) to that recently implemented and proposed in the UK (Lynn and Inner Dowsing) or in the Netherlands (Q7). 
Taking into consideration experience with offshore wind farms in current operation, the design data analysis, the basis of climate and the soil-structure interaction, the dimensionless wave height parameter $\left(H_{0}\right)$, the erosion extension ( $\left.L_{\text {ext }}\right)$ and the quantification of maximum scour depth $\left(S_{\max }\right)$ have been calibrated for a preliminary design of protections around a large diameter pile.

\section{State of the art}

\subsection{Overview of offshore wind farms}

A large number of offshore wind farms are currently operative in Europe. Monopile foundations remain the most common substructure for offshore turbines. Around $75 \%$ of all units installed since 1991 are monopiles, followed by $21 \%$ of gravity based structures (GBS) (see Fig. 1). Data collected in this research refer to both types of substructure, although information on only two offshore wind farms with gravity based foundations has been obtained.

Information from the research has been collected through several studies and papers published up to date. Wind facilities studied were selected according to information found during the investigation. Fig. 2 shows the location of the European offshore wind farms considered in this analysis.

The UK is the largest market, representing over half of all installed offshore wind capacity in Europe, and, in addition, the future is very promising there due to major support from the Crown State. Denmark, the Netherlands, Germany, Belgium and Sweden follow the UK in the development of offshore wind farms in Europe.

Table 1 contains the main information on offshore wind farms (type of foundation, maritime climate information and technical specifications of turbines) regarding this research.

During the investigation work, a large amount of information available on energy production, location, or the geometry of different wind farms in Europe was detected. Similarly, as shown in

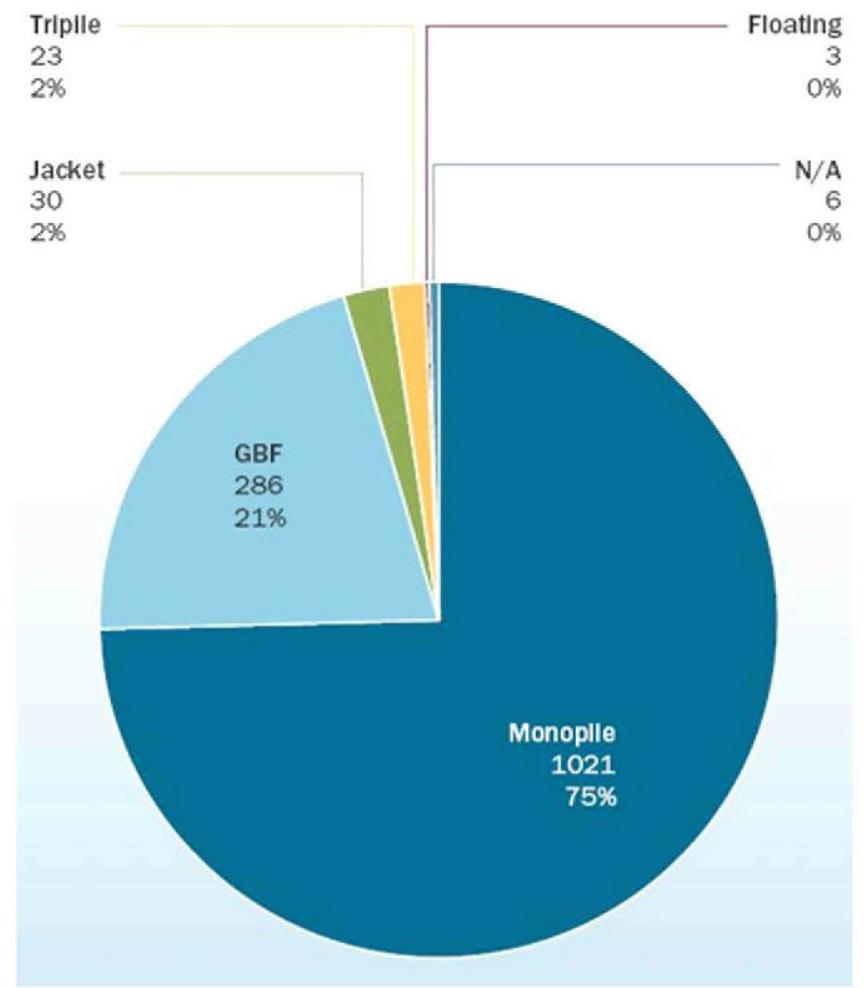

Fig. 1. Types of substructure for European offshore wind farms (online) from Ref. [11].
Table 1, a lack of information on climatic variables taken into account during the design process was also detected, such as the design wave height $\left(H_{D}\right)$ or the peak period $\left(T_{p}\right)$. This is partly due to the confidentiality present in the documentation associated to these types of project.

In this regard, recommended experience would be useful to have as would knowing the ratio between wave height and wave period at each site $(T=f(H))$. This is a ratio that would design offshore structures through knowledge of the maritime climate. The characterization of this expression is not under investigation but is within the lines of research inside the research group.

\subsection{Dimensionless wave height parameter $\left(H_{0}\right)$}

$H_{0}$ parameter is defined as $H_{S} /\left(\Delta \cdot D_{50}\right)$, where $H_{S}$ is the significant wave height, $\Delta$ is the relative mass density and $D_{50}$ is the characteristic diameter of gravel, stone or sand, and is used to classify different structures. For example, caissons or similar structures with larger armour units are related to low values of $H_{0}$ (see Fig. 3).

Maritime climate data $\left(H_{s}, T_{p}\right)$ from selected offshore wind farms were used (see Table 8 ) to characterize $H_{0}$. As discussed below under the heading of results, figures of $H_{0}$ between 6 and 15 were obtained for all offshore wind farms studied, and a new classification was proposed at the end of this research.

\section{Methodology}

In the first phase of the study, collecting information from different wind farms enabled the different formulations used so far for the prediction of maximum scour depth to be assessed.

During this phase, available information on climate variables such as wave height and characteristic wave peak period at each location, which plays an important role in the design phase of these structures, was found to be lacking. To this effect, a gap in terms of the existence of formulas connecting the wave height and period in each zone $(T=f(H))$ was also detected.

Secondly, with the data previously collected, the monomial $H_{0}$ was characterized taking into account that the existing scour protections around these structures may behave dynamically, in a similar way to that characterized by Ref. [12], defining rock slopes and beaches where the rock diameter is relatively small, with $H_{0}$ valued between 6 and 20 .

Analysis of other protections against undermining was carried out in a third phase with the information collected. During this phase, it was found that the expressions used until now for the sizing of these protections are based on variables like the pile diameter $(D)$, omitting climatic variables such as wave height and wave period ( $H$ and $T$ ) that play an important role during the design phase.

The lack of criteria for the design of scour protections taking into account climatic variables, has been associated in a fourth study phase to research for formulas taking into account variables such as [13].

A recommendation has been made for the design of the extension of scour protections as a function of wave length $(L)$ using this formulation and the data collected during the first phase.

\section{Discussion}

The following sections will describe in detail a study on the prediction of the scour phenomenon for the first and second phases, and the design analysis of its protections associated with the third and fourth phases. 


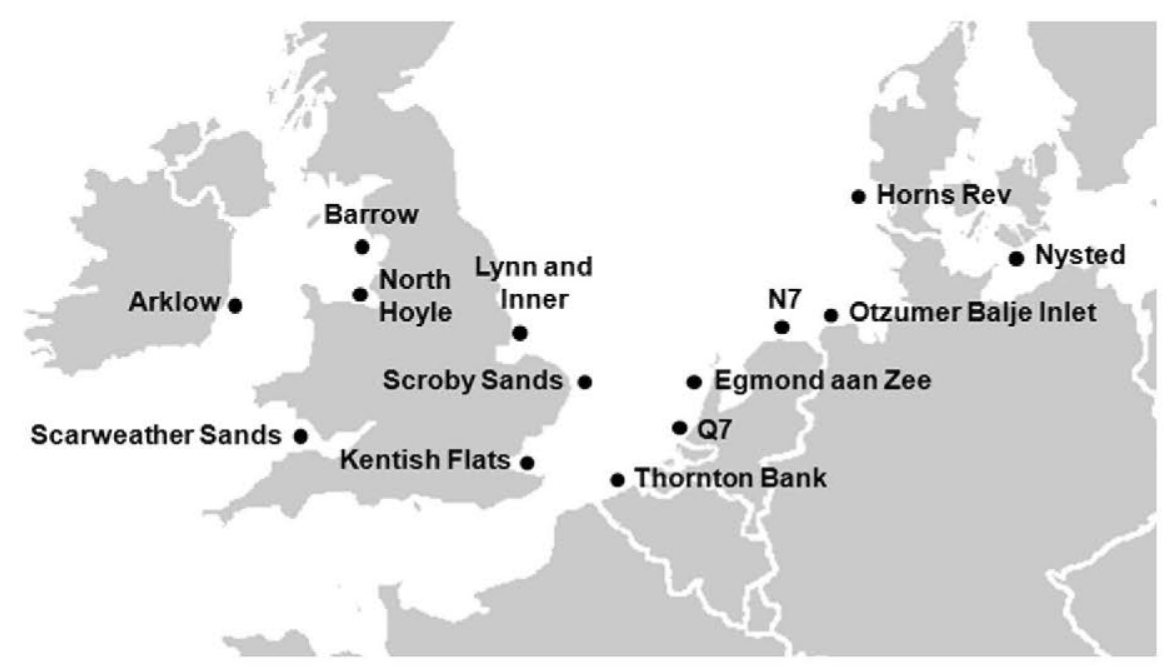

Fig. 2. Location of European wind farms studied. Own research.

\subsection{Scour phenomenon}

The scour phenomenon occurs around any structure under steady current conditions (e.g. flow in a river), or located in a marine environment, due to the increase in the sediment transport capacity by currents or by a combination of currents and waves.

Many authors, such as like $[5,14,15]$ have studied this phenomenon around a slender circular pile foundation, under steady current, wave or combined wave and current conditions. However, there is less research related to piles located in marine environments, considering the effect of waves and current at the same time.

There are two main methods for taking scour into account when designing monopile foundations. One is characterized by considering the presence of scour protection. The other, which does not include the design of scour protection, takes structural measurements into account by increasing the foundation depth or the pile diameter.

To date, many of the offshore wind farms selected have been built without considering the design of scour protections. This allowed us to avail of real data on completely unprotected structures.

To characterize the way in which scour appears in the vicinity of a pile, it is necessary to know its maximum depth and extension around the structure. Accordingly, the investigations conducted to date have been directed towards numerically predicting these parameters.

The dimensionless scour depth $(S / D, S=$ Scour depth and $D=$ Pile diameter) is a parameter that allows non-dimensional studies on the scour process around a pile to be carried out. This depends on several dimensionless parameters like the KC number, the Shields parameter or the pile Reynolds number (see Ref. [15]).

Table 2 lists the most important formulations developed for predicting the maximum scour depth. These formulations were conducted taking into account different flow conditions (steady current only, waves only, steady current or waves or steady current and waves).

Nowadays, the formula developed by Ref. [6] has been used with a coefficient of 1.25 to obtain a best-fit, through Scroby Sands data. The investigation developed by Ref. [16], was carried out to find a formula for different flow conditions. The formula proposed by Refs. [17] and [18], seem that it could over predict shallow water scour depths, considering only the pile diameter parameter. The formula proposed by Ref. [19] can be used for live-bed scour and clear-water scour. The formula obtained by Ref. [5] improves that as proposed by Ref. [18] taking into account wave action. Measurements of scouring and the action of waves and/or currents recorded from different literature were used for the parameterization and verification of the formula proposed by Ref. [20].

Table 1

Characteristic wind farm information (NA: Information not available). Own research.

\begin{tabular}{|c|c|c|c|c|c|c|c|c|c|}
\hline Name & $\begin{array}{l}\text { Year } \\
\text { installed }\end{array}$ & $\begin{array}{l}\text { Type of } \\
\text { foundation }\end{array}$ & $\begin{array}{l}\text { Monopile } \\
\text { diameter [m] }\end{array}$ & $\begin{array}{l}\text { Number of } \\
\text { turbines }\end{array}$ & $\begin{array}{l}\text { Nominal } \\
\text { capacity of } \\
\text { turbines [MW] }\end{array}$ & $\begin{array}{l}\text { Water } \\
\text { depth }[\mathrm{m}]\end{array}$ & $\begin{array}{l}\text { Significant } \\
\text { wave }\left(H_{s}[\mathrm{~m}]\right)\end{array}$ & $\begin{array}{l}\text { Peak period } \\
\left(T_{p}[\mathrm{~s}]\right)\end{array}$ & $\begin{array}{l}\text { Peak current } \\
\text { speed }\left(U_{m}[\mathrm{~m} / \mathrm{s}]\right)\end{array}$ \\
\hline N7 (Germany) & 1997 & Monopile & 6 & 1 & NA & 7 & 4.6 & 16.1 & 1.3 \\
\hline Horns rev (Denmark) & 2002 & Monopile & 4.25 & 80 & 2 & $6-14$ & 5.2 & NA & NA \\
\hline Scarweather sands (UK) & 2002 & Monopile & 2.2 & 30 & 3.6 & 6 & 3.6 & 6 & 1.1 \\
\hline Otzumer balje inlet (Germany) & 2003 & Monopile & 1.5 & 1 & NA & 11.7 & NA & NA & 1.4 \\
\hline North hoyle (UK) & 2003 & Monopile & 4 & 30 & 2 & $7-11$ & 4.78 & 6.8 & 1.17 \\
\hline Scroby sands (UK) & 2004 & Monopile & 4.2 & 30 & 2 & $3-12$ & 2.25 & NA & 1.65 \\
\hline Arklow bank (Ireland) & 2004 & Monopile & 5 & 7 & 3.6 & $2-6$ & 5.6 & NA & 2 \\
\hline Nysted (Denmark) & 2004 & Gravity based & $10.5-16$ & 72 & 2.3 & $6-9.5$ & NA & NA & NA \\
\hline Kentish flats (UK) & 2005 & Monopile & 5 & 30 & 3 & $3-5$ & 4.88 & NA & 0.9 \\
\hline Barrow (UK) & 2006 & Monopile & 4.75 & 30 & 3 & $12-18$ & 4.9 & NA & 0.8 \\
\hline Thornton bank (Belgium) & 2006 & Gravity based & $6.5-17$ & 60 & 5 & $10-24$ & 6.32 & 11.06 & 1.2 \\
\hline Egmond aan zee (Netherlands) & 2007 & Monopile & 4.6 & 36 & 3 & $16-21$ & 3.6 & 8 & 0.6 \\
\hline Lynn and inner dowsing (UK) & 2007 & Monopile & 4.74 & 54 & 3.6 & $6-13$ & 2.38 & 7.03 & 0.9 \\
\hline Princess amalia (Q7) (Netherlands) & 2008 & Monopile & 4 & 60 & 2 & $19-24$ & 7.7 & 9.7 & 1.3 \\
\hline
\end{tabular}



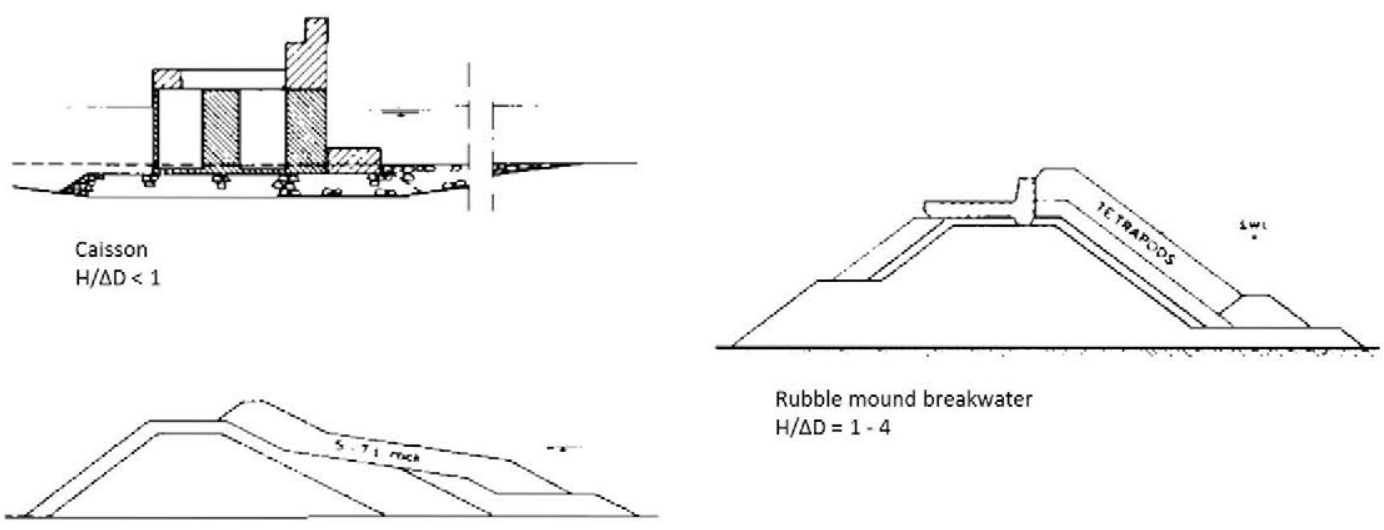

Rubble mound breakwater $\mathrm{H} / \Delta \mathrm{D}=1-4$

S-shaped breakwater $\mathrm{H} / \Delta \mathrm{O}=3-6$
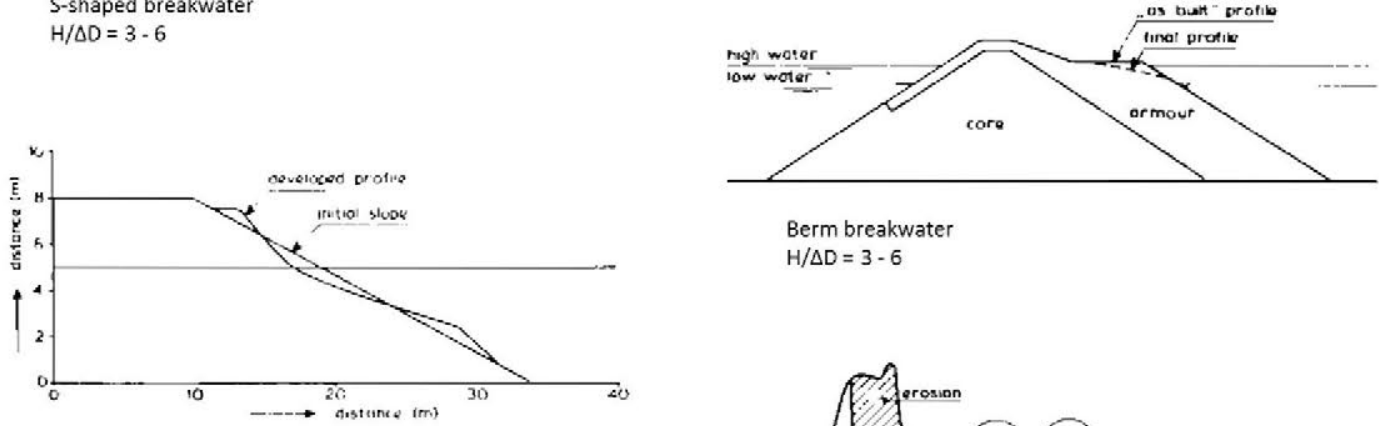

Berm breakwater

$H / \Delta D=3-6$

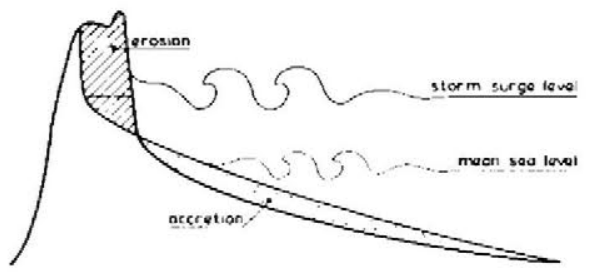

Dune erosion (sand beach) $H / \Delta D>500$

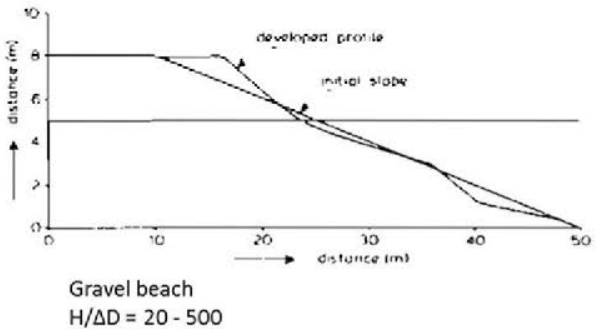

Fig. 3. Structure classification. Reproduced from Ref. [12].

Table 2

Scour depth prediction, main formulae. Own research.

\begin{tabular}{|c|c|c|c|}
\hline Authors & Year & Flow conditions & Maximum scour depth prediction \\
\hline Breusers et al. [6] & 1977 & Steady current & $\frac{S}{D} \max =1.5 \cdot D \cdot \tanh \left(\frac{h}{D}\right)$ \\
\hline Zanke [16] & 1982 & Steady current or waves & $\begin{array}{l}\frac{S}{D} \text { max }=2.5 \cdot\left(1-0.5 \cdot \frac{u c}{u}\right) \\
\frac{S}{D} w \max =K C-6\end{array}$ \\
\hline Melville et al. [17] & 1988 & Steady current & $\frac{S}{D} c \max =2.4$ \\
\hline Sumer et al. [18] & 1992 & Steady current or waves & $\begin{array}{l}\frac{S}{D} C \max =1.3 \\
\frac{S}{D} w \max =1.3 \cdot(1-\exp (-0.03(K C-6)))\end{array}$ \\
\hline $\begin{array}{l}\text { Richardson and } \\
\text { Davis (HEC-18) [19] }\end{array}$ & 1995 & Steady current & $\frac{S}{h} c \max =2 \cdot K 1 \cdot K 2 \cdot K 3 \cdot\left(\frac{b}{h}\right)^{0.65} \cdot F r^{0.43}$ \\
\hline Sumer et al. [5] & 2002 & Steady current and waves & $\frac{S}{D} c w \max =1.3 \cdot(1-\exp (-A(K C-B)))$ \\
\hline Zanke et al. [20] & 2011 & Steady current and waves & $\frac{S}{D} c w \max =2.5 \cdot\left(1-0.5 \cdot \frac{u c}{u}\right) \cdot x r e l$ \\
\hline
\end{tabular}


Table 3

Different recommendations on the parameters of the scour extension Equation (4.1.1) [25].

\begin{tabular}{ll}
\hline Author & Recommendation \\
\hline Hoffmans and Verheij, 1997 [23] & $\propto_{\text {up }} \approx \varnothing$ (angle of internal friction) \\
& $\propto_{\text {down }} \approx \frac{1}{2} \propto_{\text {up }}$ \\
Sumer and Fredsoe, 2002 [5] & $\propto_{\text {down }} \approx 25^{\circ}$ \\
\hline
\end{tabular}

Different standards and recommendations have been followed for years in these formulations. One of the most important references is Det Norske Veritas (DNV), which, in the Offshore standard [21] uses the equations developed by Ref. [18] for the calculation of scour depth. The Coastal Engineering Manual (CEM) [22], recommends the use of formulations developed by Refs. [19] and [5].

The maximum extension of scour around the pile has been studied and characterized by different authors such as [23], [5] or [24].

The scour process shape around a circular pile is known to be similar to a frustum. Thus, scour extension is defined in Ref. [25] as:

$L s=D+\operatorname{Se} \cdot\left(\cot \left(\propto_{\text {up }}\right)+\cot \left(\propto_{\text {down }}\right)\right)$

where $S_{e}$ is the scour depth in equilibrium, and $\propto_{\text {up }}$ and $\propto_{\text {down }}$, are the slopes of a scour hole.

Table 3 shows some authors' main recommendations on the Equation (4.1.1).

Authors such as [26] presented formulations for estimating the maximum scour extension, where the maximum scour depth $\left(S_{e}\right)$ and the angle of internal friction $(\varnothing)$ of sediment were present (see Equation (4.1.2)).

$L s=S e \cdot(\cot \varnothing)$

\subsection{Scour protection design}

Nowadays, there are different scour protection systems used in offshore wind farms like dumped stone riprap, stone or concrete pitching, soil-cement bagging or grouted fabric mattress [27], with the positioning of a horizontal collar/deflector [23]. The most common scour protection consists of rocks and stones (dumped stone riprap) placed around the offshore turbines. This is due to the low cost of this material and its ready availability, although it presents problems such as its installation and susceptibility to damage by currents and waves, as mentioned in Ref. [27]. In order to characterize these protections, it is important to define the stone size $\left(D_{50}\right)$ and the extension and thickness of the protection layers. Scour protection mostly has two different layers, a filter and an armour layer.

The weight of the stone is important in order to prevent its displacement. The relationship between stone diameter $D_{50}$ and average weight $W_{50}$, is defined in Ref. [28] as:

Table 4

Stone size (D50) and thickness of filter and armour layers present in different wind farms. Own research.

\begin{tabular}{lll}
\hline Name & $D_{50}[\mathrm{~m}]$ & Thickness $[\mathrm{m}]$ \\
\hline North hoyle & 0.3 & Unknown \\
Egmond aan zee & 0.4 & 1.4 (armour) \\
Thornton bank & 0.35 & 0.7 \\
Horn rev & 0.2 (filter), 0.4 (armour) & 0.5 (filter), 1 (armour) \\
Scroby sands & 0.15 & Unknown \\
Arklow bank & 0.425 & Unknown \\
\hline
\end{tabular}

Table 5

Recommendations for calculating the extension of riprap scour protections. Own research.

\begin{tabular}{ll}
\hline Author & $\begin{array}{l}\text { Scour protection } \\
\text { extension }\left(L_{\text {ext }}\right)\end{array}$ \\
\hline Bonasoundas (1973) [29] & $2.5 \mathrm{D}-4.5 \mathrm{D}$ \\
Hjorth (1975) [30] & $2.5 \mathrm{D}$ \\
Breusers and Raudkivi (1991) [31] & $3 \mathrm{D}-4 \mathrm{D}$ \\
Hoffmans and Verheij (1997) [23] & $2.5 \mathrm{D}-4 \mathrm{D}$ \\
Melville and Coleman (2000) [32] & $3 \mathrm{D}-4 \mathrm{D}$ \\
May (2002) [33] & $2 \mathrm{D}$ \\
\hline
\end{tabular}

$D_{50}=\left(\frac{W_{50}}{\rho_{s}}\right)^{1 / 3}$

Table 4 shows the stone size $\left(D_{50}\right)$, and the thickness of filter and armour layers present in wind farms on which scour protection data is available.

As shown, the size of riprap $\left(D_{50}\right)$ present in different scour protection layers (armour and filter layers) is not the same, with a smaller size being used in the filter layers.

Information available on offshore wind farms confirmed that the armour layer thickness of scour protections is usually accepted as being at least twice the average stone size $D_{50}$ (see Table) as [23] recommends, although finding information on this characteristic of scour protections was quite difficult.

Table 5 shows recommendations for calculating the extension of riprap scour protections researched by different authors to date. Formulae have mostly been designed with steady current conditions.

The figures given in Table 5 for the maximum extension of scour protection are expressed according to the pile diameter $(D)$, whilst omitting climate variables such as wave height and wave period that play an important role in the design of these structures.

Other authors, such as [26] and [34] have developed methods for calculating the optimal dimension of scour protections taking into account the maximum scour depth $\left(S_{\max }\right)$, the angle of internal friction $(\emptyset)$ on the seabed and a safety factor $\left(F_{S}\right)$, defining the scour protection extension as:

$L_{\text {ext }}=F_{S} \cdot S \cdot \cot \varnothing$

Offshore standard [21] recommends the following Formula (4.2.3) for estimating the scour protection extension in the design of offshore wind farms.

Table 6

Values of maximum scour estimations by the application of different formulae (from Refs. [6] and [21]) and available scour data of European wind farms studied (from Refs. [35-38]). Own research.

\begin{tabular}{|c|c|c|c|c|c|}
\hline \multirow[t]{2}{*}{ Name } & \multirow{2}{*}{$\begin{array}{l}\text { Monopile } \\
\text { diameter } \\
\text { [m] }\end{array}$} & \multicolumn{2}{|c|}{ Estimated scour [m] } & \multicolumn{2}{|c|}{$\begin{array}{l}\text { Available } \\
\text { scour data }[\mathrm{m}]\end{array}$} \\
\hline & & $\begin{array}{l}S_{\max } \\
\text { (Breusers) [6] }\end{array}$ & $\begin{array}{l}S_{\max } \\
(\mathrm{S} \& \mathrm{~F}, \mathrm{DNV})[21]\end{array}$ & $S_{\max }$ & $S_{\max }$ \\
\hline N7 & 6 & 7.41 & 7.80 & $1.05 \mathrm{D}$ & 6.30 \\
\hline Scarweather sands ${ }^{a}$ & 2.2 & 3.30 & 2.86 & $0.59 \mathrm{D}$ & 1.30 \\
\hline Otzumer balje inlet $^{\mathrm{a}}$ & 1.5 & 2.25 & 1.95 & 1.47D & 2.21 \\
\hline North hoyle & 4 & 5.87 & 5.20 & $0.125 \mathrm{D}$ & 0.50 \\
\hline Scroby sands & 4.2 & 5.96 & 5.46 & $1.66 \mathrm{D}$ & 6.97 \\
\hline Arklow bank & 5 & 6.25 & 6.50 & $0.86 \mathrm{D}$ & 4.00 \\
\hline Kentish flats & 5 & 7.10 & 6.50 & $0.46 \mathrm{D}$ & 2.30 \\
\hline Barrow & 4.75 & 7.10 & 6.18 & $1.21 \mathrm{D}$ & 5.74 \\
\hline Egmond aan zee & 4.6 & 6.90 & 5.98 & $0.48 \mathrm{D}$ & 2.2 \\
\hline Princess amalia (Q7) & 4 & 6.00 & 5.20 & $1.075 \mathrm{D}$ & 4.30 \\
\hline
\end{tabular}

${ }^{a}$ Met Mast data. 
Table 7

Extension of scour protections recommended for different authors in European wind farms studied. Own research.

\begin{tabular}{|c|c|c|c|c|c|c|c|}
\hline \multirow[t]{2}{*}{ Name } & \multirow[t]{2}{*}{ Monopile diameter (m) } & \multicolumn{6}{|l|}{$L_{\text {ext }}(\mathrm{m})$} \\
\hline & & $4 \mathrm{D}([23,29,31,32])$ & Cartens (Equation 4.2.2) & DNV (Equation 4.2.3) & Löffler (Equation 4.2.4) & $L / 4$ & $L / 2$ \\
\hline N7 & 6 & 24 & 30.62 & 15.83 & 40 & 32.75 & 65.50 \\
\hline Scarweather sands & 2.2 & 8.8 & 13.64 & 6.82 & 14.22 & 12.10 & 24.21 \\
\hline North hoyle & 4 & 16 & 24.26 & 12.16 & 17.06 & 13.88 & 27.76 \\
\hline Lynn and inner & 4.74 & 18.96 & 28.34 & 16.33 & 14.25 & 14.77 & 29.55 \\
\hline Egmond aan zee & 4.6 & 18.4 & 28.50 & 14.24 & 23.82 & 21.75 & 43.5 \\
\hline Princess amalia (Q7) & 4 & 16 & 24.80 & 13.40 & 34.61 & 29.82 & 59.64 \\
\hline
\end{tabular}

Table 8

Values of $H_{0}$ of European wind farms studied. Own research.

\begin{tabular}{llllr}
\hline Name & Monopile diameter $[\mathrm{m}]$ & $H_{S}[\mathrm{~m}]$ & $D_{50}[\mathrm{~m}]$ & $H_{0}=\frac{H_{S}}{\Delta^{*} D_{50}}$ \\
\hline Horns rev & 4.25 & 5.20 & 0.40 & 8.20 \\
North hoyle & 4 & 4.78 & 0.30 & 10.05 \\
Scroby sands & 4.2 & 2.25 & 0.15 & 9.46 \\
Arklow bank & 5 & 5.60 & 0.42 & 8.31 \\
Thornton bank & $6.5-17$ (GBS) & 6.32 & 0.35 & 11.39 \\
Egmond aan zee & 4.6 & 3.60 & 0.40 & 5.68 \\
\hline
\end{tabular}

$L_{\text {ext }}=\frac{D}{2}+S_{\max } \cdot \cot \varnothing$

During the fourth phase of the research, formulations were analysed where climatic variables such as wave height and wave period have been considered. This made it possible to assess flowstructure interaction through these parameters.

An example of this is the study [13] which shows that the extent of pressure distribution on the berm $\left(L_{p b}\right)$ calculated by the Sainflou theory is:
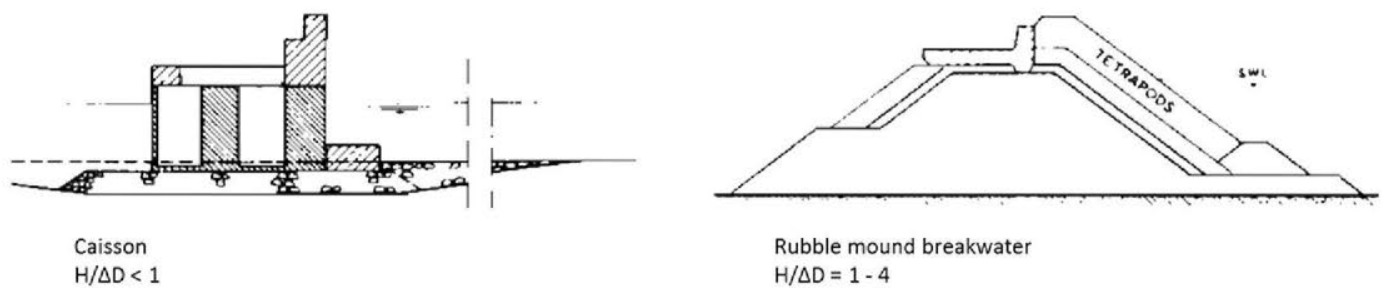

Rubble mound breakwater

$\mathrm{H} / \Delta \mathrm{D}=1-4$
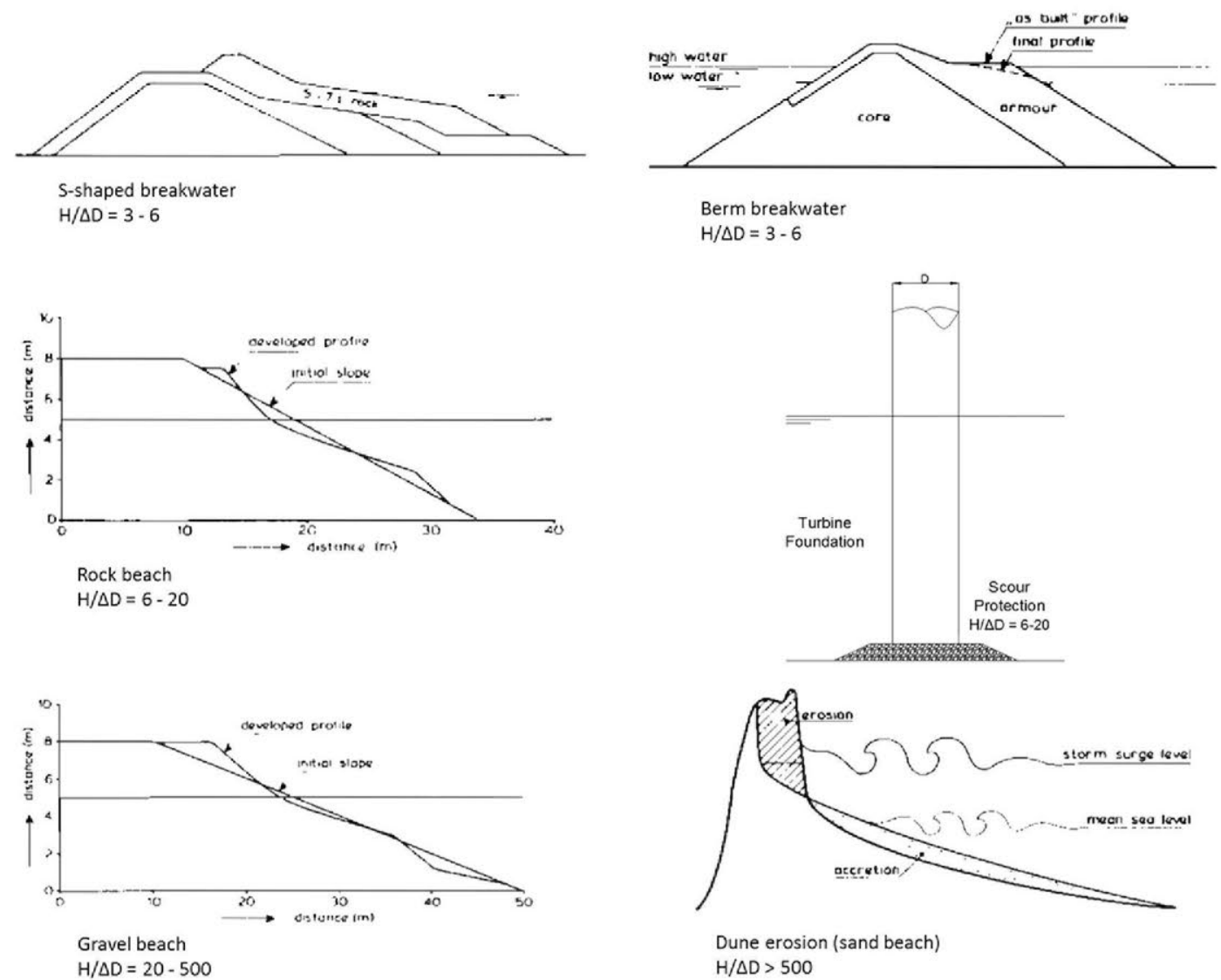

Fig. 4. Proposed classification for offshore wind turbine foundations. Modified from Ref. [12]. 
$L_{p b}=\frac{L}{2 \pi} \cdot \operatorname{arcos}\left(\frac{-\pi \cdot H}{L} \cdot \operatorname{coth} L \cdot \tanh \left(\frac{2 \cdot \pi \cdot h}{L}\right)\right)$

Considering this formula from a conservative approach would be reasonable to design scour protections with larger dimensions of $L_{p b}$

\section{Results}

Available data on technical reports and publications with regard to scour processes in European wind farms, such as [35-38], enabled the main formulations (see Table) for estimating maximum scour depth to be evaluated.

Table 6 shows the maximum calculated scour data from different formulations used in standard and technical recommendations ([21]) for the design of offshore wind farms compared with available scour data found in technical reports. As observed, the maximum scour was less than estimated in most offshore wind farms studied. Only two displayed greater scour (see Table 6, bold).

Table 7 shows the extension for scour protections recommended by different authors calculated in offshore wind farms with sufficient available data.

Results obtained applying the maximum extension recommended by different authors (4D) were more conservative than used by DNV standards.

As observed, the figures obtained by the Formula (4.2.4) were between $L / 4$ and $L / 2$.

Table shows $H_{0}$ values calculated for each European offshore wind farms where environmental actions $\left(H_{s}, T_{p}\right)$ and scour protection $\left(D_{50}\right)$ information were available and known, where $\Delta=\left(\rho_{r}\right)$ $\left.\rho_{w}\right)-1, \rho_{w}=1025 \mathrm{~kg} / \mathrm{m}^{3}$ and $\rho_{r}=2650 \mathrm{~kg} / \mathrm{m}^{3}$ (average value of mass density for a general rock protection, rubble mound and riprap).

Table 8 shows all $H_{0}$ data except the Egmond Aan Zee figure between 6 and 20. The value close to 6 of Egmond Aan Zee may be due to the correlation between $H-T$. In this offshore wind farm, the value of the peak period is low due to the wind, which is a subject that should be studied and taken into account in designing future offshore wind farms.

In his PhD Thesis [12], Van der Meer considered that for rock slopes and beaches where the diameter of the rock is relatively small, $H_{0}$ is between 6 and 20 .

We therefore propose that offshore wind farms with monopile or gravity based structure foundations, may belong to this group, with $H_{0}$ between 6 and 15. Generally, dynamic scour protections present an average riprap diameter between 0.3 and $0.4 \mathrm{~m}$.

Fig. 4 shows the classification proposed for offshore wind farms.

\section{Conclusions}

The design of scour protection must be integrated into the foundations design. In order to carry out an effective design, sediment properties, the seabed's geotechnical characteristics, environmental parameters $\left(H_{s}, T_{p}\right.$, etc.), the turbine specifications (diameter, shape of pile, etc) must be taken into account and must accurately predict the maximum scour that would occur in the absence of this protection.

In the actual data used, difficulties in obtaining wave variables and their correlation between significant wave height $\left(H_{s}\right)$, peak period $\left(T_{p}\right)$ or half wave period $\left(T_{m}\right)$, or significant wave height of wave spectrum $\left(H_{m 0}\right)$, mean period $\left(T_{02}\right)$ are noted for operating farms.

This research proposes an indicator for the value of the dimensionless monomial wave height that enables scour protection of offshore wind farms to be designed as a function of extreme metocean parameters.
Taking the first adjustments set in the design of scour protections, it would be advisable to size these structures with extensions between $L / 4$ and $L / 2$, with granular material with a dimensionless wave height parameter $\left(H_{0}\right)$ between 6 and 15 .

\section{References}

[1] Esteban MD, Diez JJ, López JS, Negro V. Integral management applied to offshore wind farms. J Coastal Res 2009;(SI 56):1204-8. Lisbon, Portugal.

[2] Esteban MD, Diez II, López IS, Negro V. Methodology for the design of offshore wind farms. J Coastal Res 2011;(SI 64):496-500. Szczecin, Poland.

[3] LeBlanc C. Design of offshore wind turbine support structures, Ph. D. thesis, TU of Denmark; 2004.

[4] Whitehouse RJS. Scour at marine structures: a manual for practical applications. London: Thomas Telford; 1998.

[5] Sumer BM, Fredsøe J. The mechanics of scour in the marine environment. Singapore: World Scientific Press; 2002.

[6] Breusers HNC, Nicollet G, Shen HW. Local scour around cylindrical piers. J Hydraulic Res IAHR 1977;15(3):211-52.

[7] Nielsen AW, Hansen EA. USA. In: Time-varying wave and current-induced scour around offshore wind turbines, vol. 5. New York: American Society of Mechanical Engineers; 2007. p. 399-408.

[8] Harris JM, Whitehouse RJS, Benson T. The time evolution of scour around offshore structures. Maritime Eng 2010;163:3-17.

[9] Zaaijer MB, Van der Tempel J. Scour protection: a necessity or a waste of money?. In: 43rd IEA topical expert meeting-critical issues regarding offshore technology and deployment, Skaerbaek, Denmark; 2004. p. 43-51.

[10] Whitehouse RJS, Harris JM, Sutherland J, Rees J. The nature of scour development and scour protection at offshore windfarm foundations. Marine Pollut Bull 2011;62:73-88.

[11] European Wind Energy Association. The European offshore wind industry key 2011 trends and statistics, Technical Report of European Wind Energy Association; 2012.

[12] Van der Meer JW. Rock slopes and gravel beaches under wave attack, Ph. D. thesis, TU Delft, Netherlands; 1988.

[13] Löfler A, Kortenhaus A. Non breaking waves - pressures on berms. In: Allsop NWH, editor. Chapter 4.6. Mast III/PROVERBS. MAS- - CT95-0041. Final report. Hydrodynamic aspects, vol. Ila; April 1999.

[14] Melville BW, Raudkivi AJ. Flow characteristics in local scour at bridge piers. J Hydraulic Res 15(4):373-80.

[15] Umeda S. Scour regime and scour depth around a pile in waves. J Coastal Res 2011;(SI 64):845-9. Szczecin, Poland.

[16] Zanke U. Scours at piles in steady flow and under the influence of waves, technical communication 54. Germany: Univ. Hannover; 1982.

[17] Melville BW, Sutherland AJ. Design method for local scour at bridge piers. J Hydraul Eng 1988;144(10):1210-26.

[18] Sumer BM, Fredsøe J, Christiansen N. Scour around vertical pile in waves. J Waterway Port Coastal Ocean Eng 1992;118(1):15-31.

[19] Richardson EV, Davis SR. Evaluating scour at bridges, hydraulic engineering circular no. 18 (HEC-18), publication no. FHWA-IP-90-017. 3rd ed. Washington D.C., USA: Federal Highway Administration; 1995.

[20] Zanke U, Hsu TW, Roland A, Link O, Diab R. Equilibrium scour depths around piles in noncohesive sediments under currents and waves. Coastal Eng 2011;58:986-91.

[21] Det Norske Veritas. Design of offshore wind turbine structures, offshore standard DNV-OS-J101; 2011 [Edition].

[22] US Army Corps of Engineers. Coastal engineering manual, engineer manual 1110-2-1100; 2002. Washington, D.C.

[23] Hoffmans GJCM, Verheij HJ. Scour manual. Rotterdam, Netherlands: A.A. Balkema; 1997. p. 205.

[24] Frigaard P, De Vos L. Offshore wind turbines situated in areas with strong currents. Esbjerg, Denmark: Laboratory Tests, Technical Report of Offshore Center Denmark; 2006

[25] De Vos L. Optimisation of scour protection design for monopiles and quantification of wave run-up, Ph. D. thesis, Universiteit Gent, Belgium; 2008.

[26] Den Boon JH, Sutherland J, Whitehouse R, Soulsby R, Stam CJM, . Verhoeven K, et al. Socur behavior and scour protection for monopile foundations of offshore wind turbines. London, UK: EWEC; 2004.

[27] Corp Rail. Scour protections (S40), RailCorp technical specifications; 2007.

[28] CIRIA/CUR. Manual on the use of rock in coastal and shoreline engineering, vol. 154. CUR; 1991

[29] Bonasoundas M. Strömungsvorgang und Kolkproblem am pfeiler, Versuchsanstalt für Wasserbau. Bericht 28. Germany: Technischen Universität München, Oskar v. Miller Institut; 1973.

[30] Hjorth P. Studies on the nature of local scour. Institute of Technology, Dept. of Water Resources Engineering; 1975.

[31] Breusers HNC, Raudkivi AJ. Scouring. Rotterdam: Balkema; 1991. p. 143.

[32] Melville BW, Coleman SE. Bridge scour. Highlands USA: Water Resources Publications; 2000 . p. 550.

[33] May RWP, Ackers JC, Kirby AM. Manual on scour at bridges and other hydraulic structures. CIRIA; 2002.

[34] Carstens T. Seabed scour by currents near platforms. In: 3rd conference on port and ocean engineering under arctic conditions. University of Alaska; 1976. p. $991-1006$. 
[35] Carroll B, Cooper B, Dewey N, Whitehead P, Dolphin T, Rees J, et al. A further review of sediment monitoring data UK: Cowrie ScourSed-09 eBook: 2010 p. 106

[36] Deutsche WindGuard GmbH, Deutsche Energie-Agentur GmbH, University of Groningen. Case study: European offshore wind farms - a survey for the analysis of the experiences and lessons learnt by developers of offshore wind farms, final report; 2007.
[37] Whitehouse RJS, Harris JM, Sutherland J, Rees J. The nature of scour development and scour protection at offshore windfarm foundation. Marine Pollut Bull 2011;62:73-88.

[38] Whitehouse RJS, Harris JM, Rees J. Dynamics of scour pits and scour protection - synthesis report and recommendations (milestones 2 and 3). Department of Energy and Climate Change; 2008. 